\title{
Early development of nephropathy in a new model of spontaneously hypertensive rat with non-insulin-dependent diabetes mellitus
}

\author{
M. Wakisaka ${ }^{1}$, K. Nunoi ${ }^{1}$, M. Iwase ${ }^{1}$, M. Kikuchi ${ }^{1}$, Y. Maki ${ }^{1}$, K. Yamamoto ${ }^{2}$, S.Sadoshima ${ }^{1}$ and M. Fujishima ${ }^{1}$ \\ ${ }^{1}$ Second Department of Internal Medicine, Faculty of Medicine, Kyushu University and \\ ${ }^{2}$ Kyushu Institute of Design, Fukuoka, Japan
}

Summary. We designed the present study to clarify whether the development of nephropathy was accelerated by a combination of hypertension and non-insulin-dependent diabetes. Spontaneously hypertensive rats with non-insulin-dependent diabetes induced by neonatal streptozotocin treatment $(25.0-75.0 \mathrm{mg} / \mathrm{kg})$ were separated into severely or mildly diabetic groups according to their non-fasting plasma glucose levels at 12 weeks of age and the findings were compared with the data on a control group treated with citrate buffer alone. The natural courses of urinary excretion rate of total protein, the molecular composition by sodium dodecyl sulfate polyacrylamide gel electrophoresis with laser desitometer and $\mathrm{N}$-acetyl- $\beta$-D-glucosaminidase were measured in the three groups from 12 weeks until 36 weeks of age. Total urinary protein in the control group decreased with age $(p<$ 0.05 ), while in the mildly diabetic group changes were nil; in the severely diabetic group, however, the excretion rates of total urinary protein and high molecular weight protein consistently and progressively increased with age $(p<0.05)$. The low molecular weight protein continuously decreased with age in the mildly diabetic and control groups $(p<0.05)$, while in the severely diabetic group there was no decrease after 28 weeks of age. The urinary $N$-acetyl- $\beta$ - $D$-glucosaminidase markedly increased $(p<0.05)$ in the severely diabetic group throughout the period compared with findings in the control group, but drastically decreased $(p<0.05)$ in the mildly diabetic group with age. There were significant correlations between the mean glycosylated haemoglobin levels and all the urinary parameters measured $(p<0.05)$. These observations suggest that development of nephropathy is accelerated by the glycaemic level in hypertensive rats. This new model should be appropriate for studying the combined effects of hypertension and diabetes mellitus on the kidney.

Key words: Non-insulin-dependent diabetes mellitus, hypertension, nephropathy, urinary protein, streptozotocin, $\mathrm{N}$-acetyl-f $f$-D-glucosaminidase.
Hypertension is often associated with diabetes mellitus and is a prominent accelerating factor for established diabetic nephropathy [1-4]. Whether a combination of hypertension and diabetes mellitus accelerates the development of nephropathy remains controversial [5-6].

We recently developed a new model of non-insulindependent diabetes mellitus in spontaneously hypertensive rats (SHR) induced by neonatal streptozotocin treatment [7-8]. The characteristics of this model are as follows: (1) hypertension develops normally and is maintained as in the non-diabetic SHR; (2) various degrees of hyperglycaemia can be achieved in the adult rats by altering the dose of streptozotocin; (3) insulin injection is not required for long-term survival. Using this model, we designed the present study to clarify the long-term combined effect of hypertension and diabetes mellitus on the development and progression of nephropathy, as revealed by total urinary protein, the molecular composition analysed by sodium dodecyl sulfate polyacrylamide gel electrophoresis with laser desitometer and $\mathrm{N}$-acetyl- $\beta$-D-glucosaminidase (NAG).

\section{Materials and methods}

Spontancously hypertensive rats from an inbred colony in our laboratory were bred in specific pathogen-free conditions in the Kyushu University animal centre. They had free access to tap water and a standard chow diet containing $51.6 \%$ carbohydrate, $24.8 \%$ protein, $7.0 \%$ minerals, $4.4 \%$ fat and $3.5 \%$ cellulose (Clea Japan Inc, Tokyo, Japan).

Neonatal streptozotocin injection was carried out as previously reported [7]. Briefly, two-day-old male SHR neonates were intraperitoneally injected via a 27 -gauge microsyringe with streptozotocin (Upjohn Co., Kalamazoo, Mich, USA) dissolved in $0.1 \mathrm{~mol} / 1$ citrate buffer $\mathrm{pH}$ 4.5. Doses of streptozotocin given were varied as 25.0 , $37.5,50.0,62.5$ and $75.0 \mathrm{mg} / \mathrm{kg}$, but the volume injected was the 
same $(4 \mu \mathrm{l} / \mathrm{g}$ body weight. Control rats were given an equivalent amount of citrate buffer alone. At 12 weeks of age, streptozotocintreated rats were separated into mildly or severcly diabetic groups according to their non-fasting plasma glucose level, i.e. $16.7 \mathrm{mmol} / \mathrm{I}$ or more as severe and the below that level as mild. There were 8 control rats, 8 mildly diabetic rats and 13 severely diabetic rats. All animals were kept until 36 weeks of age; one mildly diabetic rat which died shortly before the final assessment at 36 weeks of age was excluded.

\section{Measurements}

Blood for the determination of plasma glucose and glycosylated haemoglobin was obtained by snipping the tail of fed rats every 8 weeks. Plasma glucose was determined by Beckman Glucose Analyser 2 (Beckman Instrument, Fullerton, Calif, USA) and glycosylated haemoglobin by aminophenyl boronic acid affinity chromatography (Isolab Inc, Akron, Ohio, USA). Systolic blood pressure was measured in an unanaesthetised state by the indirect tail cuff method. Twenty-four $h$ urine samples were obtained cvery 8 weeks, using a metabolic cage. Total urinary protein was measured by the Coomassie brilliant blue method (Ohtsuka Assay Laboratory, Tokushima, Japan) and urinary NAG was measured by an enzymatic method (Shionogi Co, Tokyo, Japan). For analysis of the molecular composition of total urinary protein, sodium dodecyl sulfate polyacrylamide gel electrophoresis (SDS-PAGE) was performed with a micro-slab gel using a Laemmli buffer system [9]. A discontinuous polyacrylamide gradient was used to separate proteins in the range of 9,000-100,000 molecular weight. Protein was stained with Coomassie brilliant blue. Fach stored urine sample was mixed with an equal amount of sample buffer ( $2 \%$ sodium dodecyl sulfate, $0.025 \mathrm{~mol} / \mathrm{l}$ Tris and $0.192 \mathrm{~mol} / \mathrm{l}$ glycine). On the basis of total protein measurements, $10 \mu \mathrm{g}$ protein per sample was loaded on each lane. Bromphenyl blue was used as a tracking dye. The molecular weight was determined using SDS-PAGE molecular weight standards-low (BioRad Laboratory, Richmond, Calif, USA). The stained polyacrylamide gels were scanned using laser densitometer (Ultroscan XL 222-001, LKB Instrument, Stockholm, Sweden). We defined the protein as urinary albumin by its mobility compared with rat serum albumin. Proteins less than 32,000 dalton were defined as low molcular weight (LMW) protein and those over or equal to albumin as high molecular weight $(\mathrm{HMW})$ protein. Urine sampling was missed in one of 13 severely diabetic rats at 36 weeks of age.

\section{Statistical analysis}

Student's t-test and paired Student's t-test were used. The difference was considered significant when the $p$ value was less than 0.05 . Data are presented as the mean $\pm S E M$.

\section{Results}

Table 1 shows the changes of body weight, systolic blood pressure, urine volume, plasma glucose and glycosylated haemoglobin levels in SHR with mild or severe diabetes and control rats. Body weight in the mildly diabetic group was much the same as that in the control group while severely diabetic rats were significantly lighter than those in the other two groups $(p<$ 0.05 ). Systolic blood pressure was similar among the three groups. Urine volume was markedly increased in the severely diabetic group $(p<0.05)$, as compared with findings in the other two groups. Plasma glucose levels in the mildly diabetic group were significantly higher than in the control group $(p<0.05)$ though there was a gradual decrease with age. The mean plasma glucose level in the severely diabetic rats ranged from $18.2 \mathrm{mmol} / \mathrm{I}$ to $25.2 \mathrm{mmol} / \mathrm{l}$, that of the mildly diabetic group ranged from $7.8 \mathrm{mmol} / 1$ to $13.0 \mathrm{mmol} / \mathrm{l}$, and that of the control group from $5.8 \mathrm{mmol} / 1$ to $6.9 \mathrm{mmol} / \mathrm{l}$. Changes in the glycosylated haemoglobin levels in the mildly and severely diabetic groups were compatible with those of the plasma glucose levels. The mean value of glycosylated haemoglobin at 4 points $(12,20,28$ and 36 weeks) was $10.7 \pm 2.3 \%$ in the severely diabetic group, $6.7 \pm 0.5 \%$ in the mildly diabetic group and $4.7 \pm 0.3 \%$ in the control group.

Figure 1 shows serial changes in the urinary excretion rate of total protein during the observation period. Total urinary protein of the control group was $21.5 \pm$

Table 1. Body weight, systolic blood pressure, urine volume, plasma glucose and glycosylated haemoglobin in spontaneously hypertensive rats with mild or severe diabetes

\begin{tabular}{|c|c|c|c|c|c|c|c|c|c|}
\hline & \multirow{2}{*}{$\begin{array}{l}\text { Group } \\
\text { Control }\end{array}$} & \multirow{2}{*}{$\frac{(n)}{8}$} & \multicolumn{7}{|c|}{ Age (weeks) } \\
\hline & & & \multicolumn{2}{|l|}{12} & \multicolumn{2}{|l|}{20} & \multicolumn{2}{|l|}{28} & 36 \\
\hline Body weight $(\mathrm{g})$ & $\begin{array}{l}\text { Control } \\
\text { Mild DM } \\
\text { Severe DM }\end{array}$ & $\begin{array}{r}8 \\
7 \\
13\end{array}$ & $\begin{array}{l}250 \\
246 \\
209\end{array}$ & $\begin{array}{l} \pm 9.6 \\
\pm 6.9 \\
\pm 4.9^{a}\end{array}$ & $\begin{array}{l}321 \\
312 \\
261\end{array}$ & $\begin{array}{l} \pm 8.8 \\
\pm 9.6 \\
\pm 4.9^{3}\end{array}$ & $\begin{array}{l}348 \\
337 \\
271\end{array}$ & $\begin{array}{l} \pm 9.2 \\
\pm 12.6 \\
\pm 6.6^{\mathrm{a}}\end{array}$ & $\begin{array}{l}346 \pm 9.7 \\
345 \pm 12.8 \\
280 \pm 8.6^{6}\end{array}$ \\
\hline Systolic blood pressure $(\mathrm{mm} \mathrm{Hg})$ & $\begin{array}{l}\text { Control } \\
\text { Mild DM } \\
\text { Severe DM }\end{array}$ & $\begin{array}{r}8 \\
7 \\
13\end{array}$ & $\begin{array}{l}211 \\
210 \\
211\end{array}$ & $\begin{array}{l} \pm 5 \\
\pm 5 \\
\pm 4\end{array}$ & $\begin{array}{l}204 \\
208 \\
214\end{array}$ & $\begin{array}{l} \pm 4 \\
\pm 5 \\
\pm 4\end{array}$ & $\begin{array}{l}218 \\
210 \\
216\end{array}$ & $\begin{array}{l} \pm 8 \\
\pm 7 \\
\pm 5\end{array}$ & $\begin{array}{l}213 \pm 7 \\
228 \pm 8 \\
226 \pm 7\end{array}$ \\
\hline Urine volume ( $\mathrm{ml} /$ day) & $\begin{array}{l}\text { Control } \\
\text { Mild DM } \\
\text { Severe DM }\end{array}$ & $\begin{array}{r}8 \\
7 \\
13\end{array}$ & $\begin{array}{l}11 \\
28 \\
64\end{array}$ & $\begin{array}{l} \pm 1.4 \\
\pm 9.8 \\
\pm 8.8^{\mathrm{a}}\end{array}$ & $\begin{array}{l}15 \\
15 \\
53\end{array}$ & $\begin{array}{l} \pm 1.5 \\
\pm 1.3 \\
\pm 7.8^{\mathrm{a}}\end{array}$ & $\begin{array}{l}11 \\
15 \\
52\end{array}$ & $\begin{array}{l} \pm 1.4 \\
\pm 1.2 \\
\pm 7.8^{\mathrm{a}}\end{array}$ & $\begin{array}{l}11 \pm 1.3 \\
15 \pm 1.5 \\
41 \pm 7.0^{\mathrm{a}}\end{array}$ \\
\hline Plasma glucose $(\mathrm{mmol} / \mathrm{l})$ & $\begin{array}{l}\text { Control } \\
\text { Mild DM } \\
\text { Severe DM }\end{array}$ & $\begin{array}{r}8 \\
7 \\
13\end{array}$ & $\begin{array}{r}6 . \\
10 . \\
24 .\end{array}$ & $\begin{array}{l}9 \pm 0.3 \\
\pm \pm 1.1^{\mathrm{a}} \\
\pm 0.9^{\mathrm{a}}\end{array}$ & $\begin{array}{r}6 . \\
13 . \\
25 .\end{array}$ & $\begin{array}{l}5 \pm 0.2 \\
\pm 1.2^{\mathrm{a}} \\
2 \pm 1.1^{\mathrm{a}}\end{array}$ & & $\begin{array}{l}2 \pm 0.2 \\
9 \pm 0.6^{\mathrm{a}} \\
1 \pm 1.3^{\mathrm{a}}\end{array}$ & $\begin{array}{r}5.8 \pm 0.2 \\
7.8 \pm 0.9^{\mathrm{a}} \\
18.2 \pm 1.8^{\mathrm{a}}\end{array}$ \\
\hline
\end{tabular}

Results are mean \pm SEM, DM: diabetes mellitus, GHb: glycosylated haemoglobin. ${ }^{a} p<0.05$ vs control 


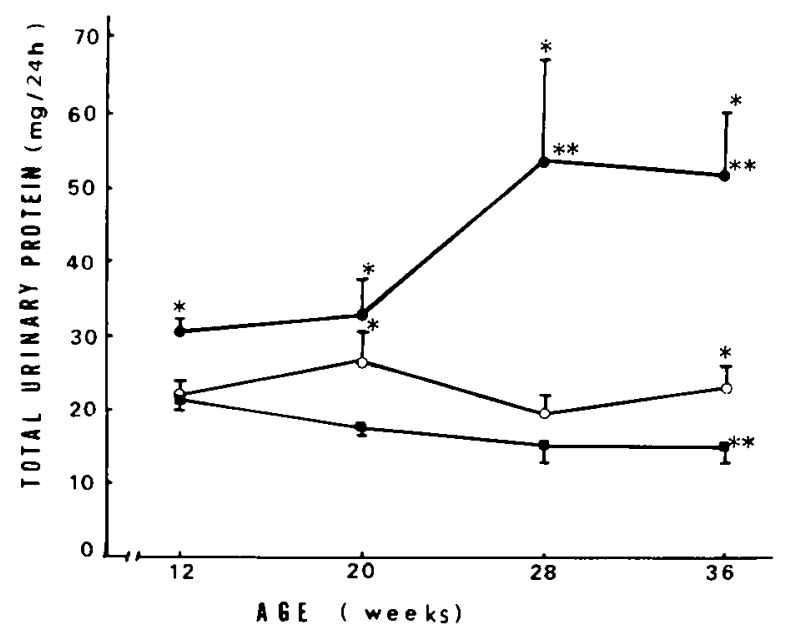

Fig. 1. Serial changes of total urinary protein. Diabetic rats were separated into mildly or severely diabetic groups according to their nonfasting plasma glucose level at 12 weeks of age, namely $16.7 \mathrm{mmol} / 1$ or more as severe and the below that level as mild. $\mathbf{D}$ control group $(n=8)$, O mildly diabetic group $(n=7)$, o severely diabetic group ( $n=13$ ). ${ }^{*} p<0.05$ (vs control group), ${ }^{* *} p<0.05$ (vs at 12 weeks of age in each group)
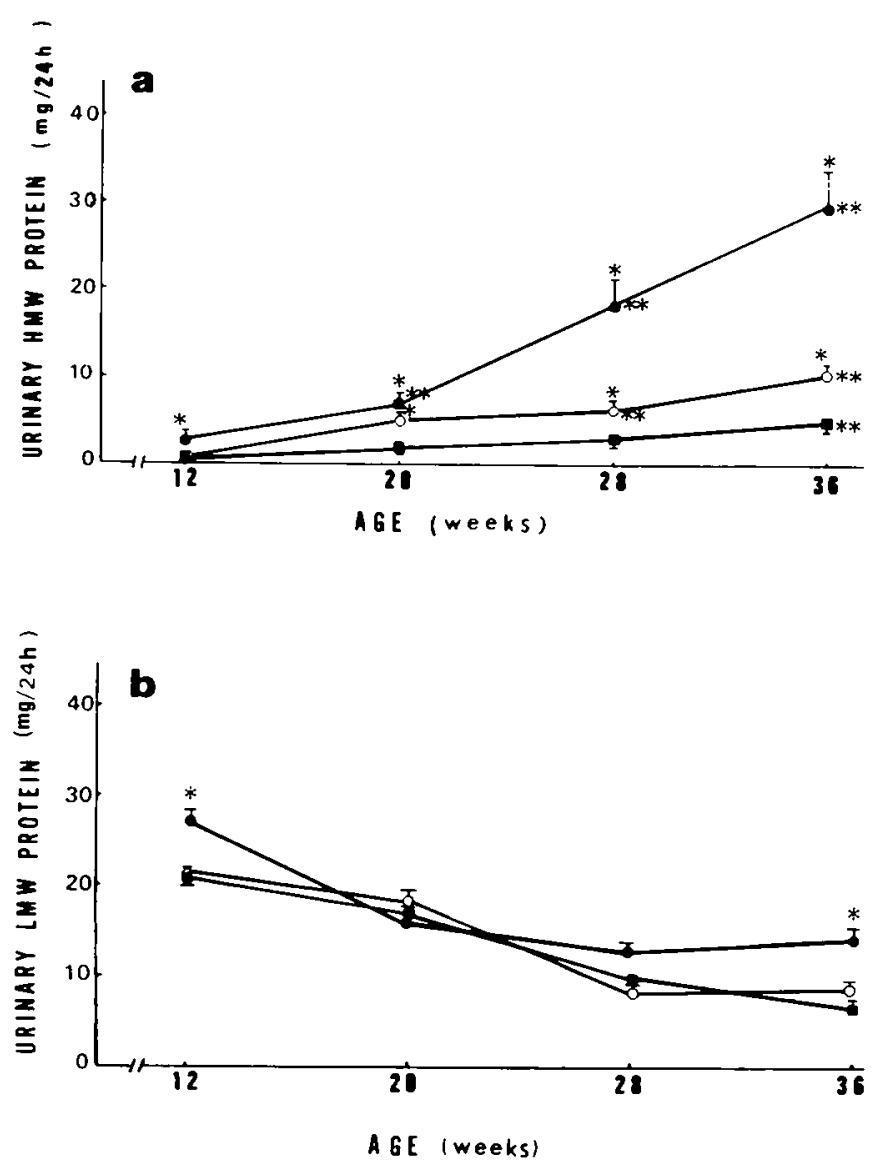

Fig. 2a and b. Serial changes of urinary high molecular weight (HMW) protein (a) and low molecular weight (LMW) protein (b). - control group $(n=8)$, O mildly diabetic group $(n=7)$, severely diabetic group $(n=13) .{ }^{*} p<0.05$ (vs control group), ${ }^{* *} p<0.05$ (vs at 12 weeks of age in each group)

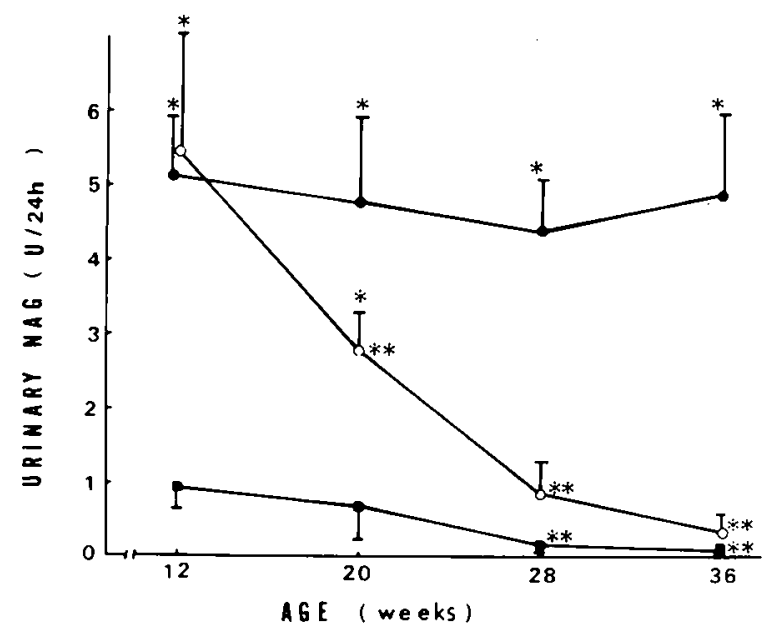

Fig.3. Serial changes of urinary $\mathrm{N}$-acetyl- $\beta$-D-glucosaminidase (NAG). control group $(n=8)$, O mildly diabetic group $(n=7)$, - severely diabetic group $(n=13) .{ }^{*} p<0.05$ (vs control group) $* * p<0.05$ (vs at 12 weeks of age in each group)

$1.7 \mathrm{mg} / 24 \mathrm{~h}$ at 12 weeks and gradually decreased to $15.2 \pm 1.7 \mathrm{mg} / 24 \mathrm{~h}$ at 36 weeks $(p<0.05)$. In the mildly diabetic group, it was the same as the control group at 12 weeks $(21.9 \pm 1.9 \mathrm{mg} / 24 \mathrm{~h})$ but thereafter it remained fairly constant, and at 20 weeks and 36 weeks the difference became significant compared with the control group $(p<0.05)$. On the other hand, in the severely diabetic group, it was $30.5 \pm 1.7 \mathrm{mg} / 24 \mathrm{~h}$ at 12 weeks, followed by a significant and progressive increase to $51.9 \pm 8.0 \mathrm{mg} / 24 \mathrm{~h}$ at 36 weeks $(p<0.05$ vs 12 weeks of age). The level was 1.5 -fold higher at 12 weeks and 3.6-fold higher at 36 weeks than that in control group respectively.

Figure 2 shows serial changes in the urinary HMW and LMW proteins during the observation periods. Urinary HMW protein in the control group increased slightly but significantly from $0.2 \pm 0.1 \mathrm{mg} / 24 \mathrm{~h}$ to $5.4 \pm 1.2 \mathrm{mg} / 24 \mathrm{~h}(p<0.05)$; in the mildly diabetic group it increased moderately and significantly from $0.4 \pm 0.2 \mathrm{mg} / 24 \mathrm{~h}$ to $10.5 \pm 1.1 \mathrm{mg} / 24 \mathrm{~h} \quad(p<0.05)$, while in the severely diabetic group it increased more progressively from $3.4 \pm 0.7 \mathrm{mg} / 24 \mathrm{~h}$ to $28.5 \pm$ $4.5 \mathrm{mg} / 24 \mathrm{~h}$, especially after 20 weeks of age. On the other hand, the urinary LMW protein decreased significantly in the control group from $21.1 \pm 1.6 \mathrm{mg} / 24 \mathrm{~h}$ to $7.0 \pm 1.1 \mathrm{mg} / 24 \mathrm{~h} \quad(p<0.05)$, and from $21.1 \pm$ $5.6 \mathrm{mg} / 24 \mathrm{~h}$ to $8.7 \pm 1.9 \mathrm{mg} / 24 \mathrm{~h}$ in the mildly diabetic group $(p<0.05)$. There were similar findings in the severely diabetic group where urinary LMW protein decreased from 12 weeks $(27.8 \pm 1.8 \mathrm{mg} / 24 \mathrm{~h})$ until 20 weeks of age $(16.7 \pm 7.8 \mathrm{mg} / 24 \mathrm{~h})(p<0.05)$ but it

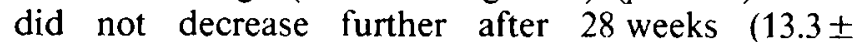
$5.0 \mathrm{mg} / 24 \mathrm{~h}$ ); rather, there was a slight increase with age. The level in the severely diabetic group at 36 weeks of age was $14.3 \pm 2.3 \mathrm{mg} / 24 \mathrm{~h}(p<0.05$ vs control group). 

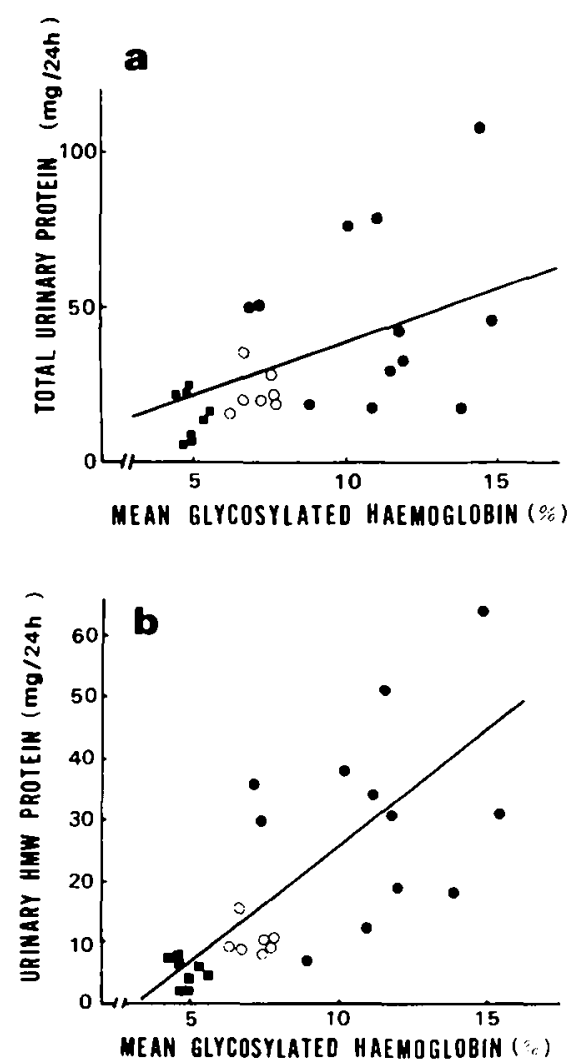
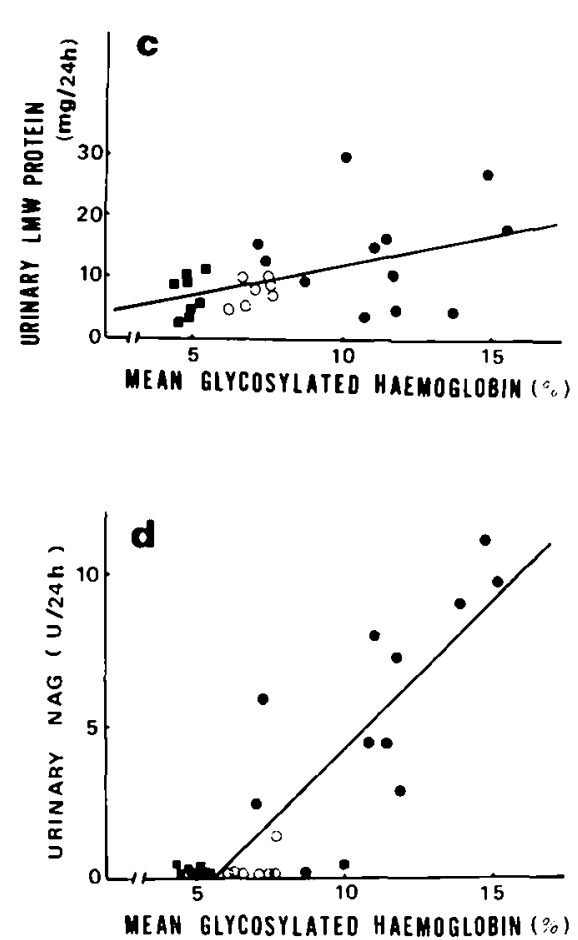

Fig. 4a-d. Correlations between the mean glycosylated haemoglobin during the observation period and the total urinary protein (a: $r=0.58, p<$ 0.05 ), HMW protein (b: $r=0.66, p<$ $0.01)$ and LMW protein (c: $r=0.47$, $p<0.05)$ and NAG $(\mathbf{d}: r=0.83, p<$ $0.001)$ at 36 weeks of age. control group ( $n=8$ ), $\bigcirc$ mildly diabetic group $(n=7)-$ severely diabetic group $(n=12)$
Figure 3 shows serial changes in the urinary excretion rate of NAG. Urinary NAG in the conrol group decreased gradually from $0.94 \pm 0.28 \mathrm{U} / 24 \mathrm{~h}$ to $0.09 \pm$ $0.02 \mathrm{U} / 24 \mathrm{~h}(p<0.01)$, and that of the mildly diabetic group decreased drastically from $5.45 \pm 1.38 \mathrm{U} / 24 \mathrm{~h}$ to $0.35 \pm 0.25 \mathrm{U} / 24 \mathrm{~h}(p<0.01)$, while that of the severely diabetic group was $5.14 \pm 0.73 \mathrm{U} / 24 \mathrm{~h}$ at 12 weeks and was sustained above $4.00 \mathrm{U} / 24 \mathrm{~h}$ during the following 24 weeks.

Figure 4 shows correlations among the urinary parameters (4a: total protein, $4 \mathrm{~b}$ : $\mathrm{HMW}$ protein, $4 \mathrm{c}$ : LMW protein and $4 \mathrm{c}$ : NAG) at 36 weeks of age and the mean glycosylated haemoglobin during the observation period. Significant positive correlations were seen between the mean glycosylated haemoglobin and total urinary protein $(r=0.58, p<0.05)$, urinary HMW protein $(r=0.66, \quad p<0.01)$, urinary LMW protein $(r=0.47, p<0.05)$ and NAG $(r=0.83, p<0.001)$ respectively.

\section{Discussion}

Some experimental studies have been reported on the combined effects of hypertension and diabetes mellitus on the kidneys. Hashimoto noted a severely diabetic glomerulosclerosis in 18-month-old SHR with alloxaninduced short-term diabetes [10], and Mauer et al. demonstrated that the glomeruli of the unclipped kidney were severely affected compared with findings in the clipped kidney in a rat model of streptozotocin-in- duced diabetes with renovascular hypertension [11]. These models are not so appropriate for studying the effects of hypertension and diabetes mellitus on kidneys, because the clipped kidney is not a good control and the diabetes induced by adult alloxan or streptozotocin treatment was so severe that few rats survived for a long time without insulin injection [5-6]. Therefore, our new model of non-insulin-dependent diabetes in SHR induced by neonatal streptozotocin treatment is more appropriate for studying renal damage by the long-term combination of hypertension and diabetes mellitus.

We analysed the molecular composition of total urinary protein using sodium dodecyl sulfate polyacrylamide gel electrophoresis with laser densitometer. Wiggins et al. showed that stored urinary albumin forms a polymer and some of the albumin appeared as high molecular weight protein in an analysis using sodium dodecyl sulfate polyacrylamide gel electrophoresis, when the sample was analysed under non-reducing conditions [12]. Therefore, we defined the protein with a molecular weight over or equal to albumin as the HMW protein. It is generally accepted that the appearance of HMW protein in the urine means organic damage to the glomerular basement membrane [13]. Inomata et al. reported that the high molecular weight protein dominant urine was present according to the severity of the diabetic complications and that low molecular weight protein dominant urine was seen in the early stages of diabetic nephropathy [14]. 
In the present study, marked increases in total urinary protein and urinary HMW protein were clearly evident in the severely diabetic SHR. These increases could not be explained by only one of the chronic effects of hypertension and hyperglycaemia. Feld et al. showed that total urinary protein of non-diabetic SHR decreased from 9 weeks until 33 weeks of age and increased after 45 weeks of age with glomerular lesions such as hyalinisation and pericapsular fibrosis. Furthermore, they pointed out that urinary albumin and globulins of non-diabetic SHR increased and urinary low molecular weight protein decreased after 13 weeks of age [15]. Urinary proteins of our control group changed in the same manner. The early decrease in LMW protein in the control group may be explained by the effect of maturation of the animal and the gradual increase of urinary HMW protein in the control group may be explained by the damage of filtration barrier induced by hypertension [15]. According to the chronic effect of hyperglycaemia on nephropathy, Rasch showed that diabetic female Wistar rats had a significantly greater (about: 2.5-fold of control rats) urinary albumin excretion and mildly significant morphological changes such as an increase of basement membrane thickness and mesangial lesions after 24 weeks of diabetes, as compared to the control group [16]. Weil et al. noted a mild increase of mesangial matrix in ultrastructural studies on streptozotocin-diabetic rats after 12 weeks of diabetes [17]. Our SHR with severe diabetes had a higher excretion rate of HMW protein (about 6-fold that of control rats) than that expected in rats with diabetes only [5, 16]. The marked increase in urinary HMW protein in the severely diabetic rats might derive from organic glomerular basement membrane damage by the combined effects of hyperglycaemia and hypertension.

Renal damage in SHR with adult streptozotocin diabetes has been reported. Bank et al. reported that total urinary protein was not increased in diabetic SHR compared with that in non-diabetic SHR [6]. Cooper et al., however, reported that diabetic SHR had higher levels of proteinuria did the non-diabetic SHR, diabetic Wistar Kyoto rats or non-diabetic Wistar Kyoto rats during an observation period of 24 weeks [5]. Our data on the severely diabetic group and control group are compatible with those of Cooper et al. except that total urinary protein and HMW protein in our severely diabetic group were significantly higher than those of the control group even 12 weeks after the streptozotocin injection. This may be because the diabetic state in Cooper's study was so severe that the blood pressure might have fallen markedly at 16 weeks after streptozotocin injection and the animals could not survive.

The hyperfiltration theory concerning initiation and progression of diabetic nephropathy suggests that the glomerular transcapillary hydraulic pressure gradient and the renal plasma flow are increased in dia- betic patients and that these changes might be responsible for albuminuria and mesangial expansion and clinical diabetic nephropathy [18]. On the other hand, Meyer et al. noted an increased glomerular transcapillary hydraulic pressure gradient in hypertensive rats [19]. Renal ablation which produces hyperfiltration of the remnant kidney leads to a severe non-selective proteinuria and organic renal damage in the SHR, as compared to findings in those treated with antihypertensive drugs [20]. Earlier development of nephropathy in our hypertensive and diabetic rats might be due to acceleration of the glomerular hyperfiltration by the combination of hyperglycaemia and hypertension.

The urinary excretion of NAG, a lysosomal enzyme of the proximal tubule of the kidney, has been shown to increase not only in diabetic patients but in hypertensive ones [21-24], and the rise in urinary NAG suggests organic damage of the renal proximal tubule or the effect of hyperglycaemia on the renal tubules [24]. Urinary LMW protein increases in the presence of renal proximal tubular damage. The urinary NAG and LMW proteins in the severely diabetic group remained high, particularly after 28 weeks of age, irrespective to the gradual decrease in glycaemic level. Weil et al. noted the degenerative changes in the proximal tubules of streptozotocin-diabetic rats after 12 weeks of diabetes [17] and Sasser et al. noted the tubular basement membrane thickening after 20 weeks of diabetes [25]. Some of the increases in urinary NAG and LMW protein in the severely diabetic group at 36 weeks of age might derive from organic proximal tubular damage induced by the combined injurious effects of hyperglycaemia and hypertension as well as the increase in urinary HMW protein by the glomerular basement membrane damage. In contrast with these findings in severly diabetic rats, urinary NAG excretion continuously decreased with age in control rats as well as the urinary LMW protein probably associated with maturation. On the other hand, the rise in urinary NAG at the early stage in mildly diabetic rats was marked and the decrease over the observation period was drastic. The level at the early stage might be maximally elevated, probably due to the combined effects of hyperglycaemia and the immaturity of proximal tubule and other unknown mechanisms. Further study will be needed.

The present study shows that the combination of hypertension and hyperglycaemia accelerated not only the progression of the established nephropathy but also the early development of nephropathy itself. The more severe hyperglycaemia and the higher mean glycosylated haemoglobin during the observation period would be associated with the more severe nephropathy seen in the SHR. Therefore, glycaemic control is essential to prevent the early development of nephrophathy in diabetic patients with hypertension.

Acknowledgements. We thank Ms. M.Ohara for valuable editorial assistance. 


\section{References}

1. Viberti G, Keen $H$ (1986) The patterns of proteinuria in diabetes mellitus: relevance to pathogenesis and prevention of diabetic nephropathy. Diabetes 33: 686-692

2. Mogensen CE (1983) Long-term antihypertensive treatment reduces rate of decline in kidney function in diabetic nephropathy. Lancet I: $1175-1179$

3. Mogensen CE (1982) Long-term antihypertensive treatment inhibiting progression of diabetic nephropathy. $\mathrm{Br}$ Med J 285: 685-688

4. Parving HH, Andersen AR, Oxenboll B, Christensen JS (1981) Diabetic nephropathy and hypertension. Diabetologia 21: 313

5. Cooper ME, Allen TJ, Jerus G, Doyle AE (1986) Accelerated progression of diabetic nephropathy in the spontaneously hypertensive rat. Clin Exper Pharmacol Pathol 13: 655-662

6. Bank N, Klose R, Aynedjian HS, Nguyen D, Sablay LB (1987) Evidence against increased glomerular pressure initiating diabetic nephropathy. Kidney Int 31: 898:-905

7. Iwase M, Kikuchi M, Nunoi K, Wakisaka M, Maki Y, Sadoshima S, Fujishima M (1986) A new model of Type 2 (non-insulindependent) diabetes mellitus in spontaneously hypertensive rats: diabetes induced by neonatal streptozotocin treatment. Diabetologia 29: 808-811

8. Iwase M, Kikuchi M, Nunoi K, Wakisaka M, Maki Y, Sadoshima S, Fujishima M (1987) Diabetes induced by neonatal streptozotocin treatment in spontaneously hypertensive and normotensive rats. Metabolism 36: 654-657

9. Laemmli UK (1978) Cleavage of structural proteins during assembly of the head of bacteriophage T4. Nature 227: 680-685

10. Hashimoto $Y$ (1969) Effect of alloxan diabetes induced in spontaneously hypertensive rats. Jpn Cir J 33: 1315-1338

11. Mauer SM, Steffes MW, Azar S, Sandberg SK, Brown DM (1978) The effect of Goldblatt hypertension on development of glomerular lesions of diabetes mellitus in the rat. Diabetes 27: $738 \cdots 744$

12. Wiggins RC, Kshrisagar B, Kelsch RC, Wilson BS (1986) Fragmentation and polymeric complexes of albumin in human urine. Clin Chim Acta 149: 155-163

13. Kanwer YS (1984) Biophysiology of glomerular filtration and proteinuria. Lab Invest 51: 7-21

14. Inomata $S$, Ito $M$, Osawa $Y$, Inoue $M$, Inoue $S$, Masamune $O$ (1984) Analysis of urinary protein in diabetes mellitus. J Japan Diab Soc 27: 591-599

15. Feld LG, Van Liew JB, Galaske RG, Boylan JW (1977) Selectivi- ty of renal injury and proteinuria in spontaneously hypertensive rats. Kidney Int 22: 332-343

16. Rasch R (1980) Prevention of diabetic glomerulopathy in streptozotocin diabetic rats by insulin treatment. Diabetologia 18 : 413-416

17. Weil R, Nozawa M, Koss M, Weber C, Reemtsma K, Macintosh $\mathrm{R}$ (1976) The kidney in streptozotocin diabetic rats. Arch Pathol Lab Med 100: 37-49

18. Hostetter TH, Rennke HG, Brenner BM (1982) The case for intrarenal hypertension in the initiation and progression of diabetic and other glomerulopathies. Am J Med 72: 375-380

19. Meyer TW, Anderson S, Rennke HG, Brenner B (1987) Reversing glomerular hypertension stabilizes established glomerular injury. Kidney Int 31: 752-759

20. Tsuruda H, Okuda S, Onoyama K, Oh Y, Fujishima M (1986) Effect of blood pressure on the progress of renal deterioration in rats with renal mass reduction. J Lab Clin Med 107: 43-50

21. Simon G, Morioka S, Synder DK (1984) Increased serum and urinary $\mathrm{N}$-acetyl- $\beta$-D-glucosaminidase activity in human hypertension: early indicator of renal dysfunction. Clin Exp Hypertens [A] A6(4): 879-896

22. Wellwood JM, Ellis BG, Price RG, Hammond $\mathrm{K}$, Thompson AE, Jones NF (1975) Urinary $\mathrm{N}$-acetyl- $\beta$ - $\mathrm{D}$-glucosaminidase activities in patients with renal disease. Br Med J 3: 408-411

23. Whiting PH, Roth IS, Borthwick L (1978) Serum and urine Nacetyl- $\beta$-D-glucosaminidase in diabetes on diagnosis and subsequent treatment and stable insulin dependent diabetes mellitus. Clin Chim Acta 92: 459-463

24. Watanabe $Y$, Nunoi K, Maki Y, Nakamura Y, Fujishima $M$ (1987) Contribution of glycemic control to the levels of urinary $\mathrm{N}$-acetyl- $\beta$-I)-glucosaminidase (NAG), total protein, $\beta_{2}$-microglobin and serum NAG in type 1 (insulin-dependent) diabetes mellitus without macroalbuminuria. Clin Nephrol 28: 227-231

25. Sasser BW, Poffenbarge PL (1983) Nonenzymatic glycosylation of renal tubular basement membrane. Diabetes 32 [Suppl. 1]; 31A

Received: 17 November 1987

and in revised form: 29 February 1988

Dr. M. Wakisaka

Second Department of Internal Medicine

Faculty of Medicine

Kyushu University

3-1-1 Maidashi, Higashi-ku

Fukuoka 812

Japan 